\title{
Tensile Bond Strength and Curing Gap Formation of a Dentin Bonding Resin
}

\author{
Michael F. BURROW, Momoko HAYASHIDA, Tadashi NEGISHI, Toru NIKAIDO, \\ Junji TAGAMI, Toshio TAKATSU and Hiroyasu HOSODA \\ Department of Operative Dentistry, Tokyo Medical and Dental University, \\ 5-45, Yushima 1-chome, Bunkyo-ku, Tokyo 113, Japan
}

Received May 14, 1993/Accepted October 15, 1993

\begin{abstract}
Tensile bond strength and contraction gap tests were carried out using a new dentin bonding resin in association with various dentin conditioning and priming materials in vitro. For the tensile bond test, significant differences were found between the nonconditioned and conditioned dentin, and the primed and non-primed dentin surfaces. The strongest bond was obtained using a combination of phosphoric acid conditioning and priming with HEMA in glutaraldehyde at $151.3 \mathrm{kgf} / \mathrm{cm}^{2}$. Gap test results showed the presence of gaps in all of the test groups, but with variation in the extent of gap formation. A not significant, inverse correlation was determined between the tensile bond strength and gap tests $(R=-0.65)$. The new bonding resin obtained good bond strengths in all cases, but high bond strengths can only be obtained with a combination of etching and priming. Similarly, the smallest gaps were associated with the etched and primed groups.
\end{abstract}

Key words : Dentin bonding, Tensile bond test, Curing contraction gap test

\section{INTRODUCTION}

With recent trends showing the increased use of composite resin restorations, particularly for esthetic dental procedures ${ }^{1)}$, the need for a strong dentinal bond is necessary to ensure maximum adhesive retention. Over the last several years, various new bonding systems have been introduced; however, most require numerous steps to be carried out prior to actual placement of the bonding resin ${ }^{2-4}$. Although good bond strengths have been achieved, the many steps required for bonding may lead to an increased possibility for operator error, and hence bond failure, as well as increased chairside time. Thus, a bonding system that has only one or two steps for preparing the dentinal surface prior to the placement of the bonding resin is advantageous to the clinical operator.

However, in association with a good tensile bond strength, the bonding system must also adhere in such a manner to ensure that curing contraction gap formation does not occur after placement and curing of the resin composite filling material ${ }^{5,6}$. This aspect may even be considered to be more important than a high tensile bond strength to dentin, since a sound seal between tooth and filling material will ensure pulpal protection from the invasion of bacteria, and ingress of oral fluids ${ }^{7}$. Recently a light-cured, phosphate ester type dentin bonding resin, PA, was introduced which the manufacturer claims to be able to obtain good bond strengths to dentin without any surface pretreatment.

The aim of this study was to investigate the tensile bond strength, and curing contraction 
gap formation of PA in association with various dentin surface conditioning agents and primers. These results were also compared against a widely used dual cured, phosphate ester type dentin bonding resin, PB used as a baseline control.

\section{MATERIALS AND METHODS}

Freshly extracted bovine incisor teeth, stored at $-4^{\circ} \mathrm{C}$, were used for both the tensile bond and gap tests. Ten specimens were used for each experimental group for both of the tests.

The materials, codes, batch numbers, and manufacturers used are listed in Table 1. The different experimental group's combinations of conditioning, priming, and bonding are shown in Table 2. The dentin conditioning agents consist of firstly, KE, which is a thixotropic solution of $37 \%$ phosphoric acid, and secondly, a gel solution, CA, comprised of $10 \%$ citric acid in $20 \%$ calcium chloride ${ }^{8}$. The priming agents used were, GL, which contains $35 \%$ aqueous HEMA (2-hydroxyethylmethacylate in glutaraldehyde), and SA consisting of a $3 \%$ solution of $\mathrm{N}$-methacryloyl 5-aminosalicylic acid in ethanol ${ }^{9,10)}$.

The procedure followed for the tensile bond test was to prepare a flat dentin surface finished with wet 600 grit silicon carbide paper. Following this, a vinyl tape, in which a 4 $\mathrm{mm}$ diameter hole was cut, was placed on the finished surface to demarcate the bonding area. In the case where the surface was conditioned, this was carried out for a period of $40 \mathrm{~s}$, then washed and dried with oil-free compressed air. The primers were left in situ for $60 \mathrm{~s}$ prior to drying with air, after which the bonding resin was placed, lightly air blown to evaporate the solvents, and then light cured for $20 \mathrm{~s}$. A $1 \mathrm{~mm}$ thick layer of filled resin composite (CB) was placed, covered with a celluloid matrix strip and glass slide, and light cured for a further $40 \mathrm{~s}$ following which a stainless steel rod, used for the tensile test, was cemented vertically

Table 1 Codes, materials, manufacturers and batch numbers

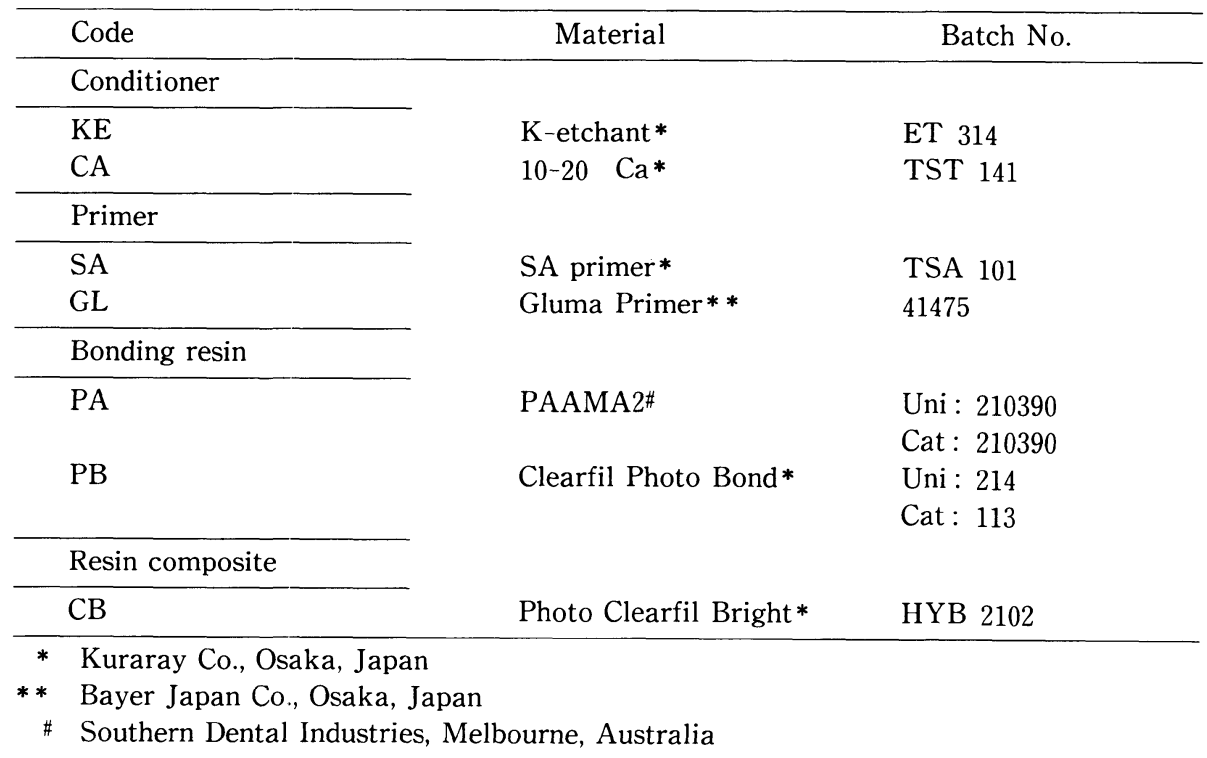


using a resin cement \#. The specimens were stored in water at $37^{\circ} \mathrm{C}$ for 24 hours prior to testing.

The tensile bond test was carried out using a universal type testing machine ${ }^{\circledR}$ with a crosshead speed of $2 \mathrm{~mm} / \mathrm{min}$. The bond strength was expressed as the mean breaking force per unit area, and statistically analyzed using Duncan's new multiple range test at the $95 \%$ level of confidence.

The gap test was carried out by preparing a $3 \mathrm{~mm}$ deep labial cavity at the cementoenamel junction (CEJ), with the cavity extension placed $2 \mathrm{~mm}$ above the CEJ into the enamel and $1 \mathrm{~mm}$ below onto the root face using a number 31 high-speed diamond stone ${ }^{\circledR}{ }^{\circledR}$ under air -water coolant.

The cavity shape was designed so as to be non-retentive, with no bevel placed on the enamel margin (Fig. 1). The procedure of conditioning, priming, and bonding was identical to that of the tensile bond test. The resin composite filling material was bulk placed and

Table 2 Treatment groups

\begin{tabular}{cccl}
\hline Group No. & $\begin{array}{c}\text { Surface } \\
\text { conditioning }\end{array}$ & Primer & Bonding resin \\
\hline 1 & - & - & $\mathrm{PA}$ \\
2 & - & - & $\mathrm{PA}(60 \mathrm{~s}){ }^{*}$ \\
3 & $\mathrm{KE}$ & - & $\mathrm{PA}$ \\
4 & $\mathrm{KE}$ & - & $\mathrm{PA}(20 \mathrm{~s}) *$ \\
5 & $\mathrm{KE}$ & $\mathrm{GL}$ & $\mathrm{PA}$ \\
6 & $\mathrm{KE}$ & $\mathrm{SA}$ & $\mathrm{PA}$ \\
7 & $\mathrm{CA}$ & - & $\mathrm{PA}$ \\
8 & $\mathrm{CA}$ & - & $\mathrm{PA}(20 \mathrm{~s}) *$ \\
9 & $\mathrm{KE}$ & - & $\mathrm{PB}$ \\
\hline
\end{tabular}

* Time before curing

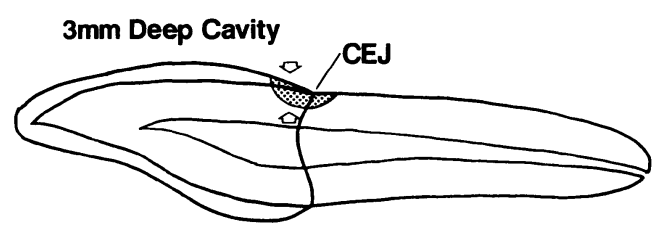

Fig. 1 A schematic diagram showing the location and outline form of the cavity placed at the CEJ of the bovine tooth. Incisally the cavity extends $2 \mathrm{~mm}$ up onto the labial surface in enamel and $1 \mathrm{~mm}$ down from the CEJ onto the root surface. The cavity depth is $3 \mathrm{~mm}$.

\# Panavia EX, Kuraray Co., Osaka, Japan

@ Autograph AG-500, Shimadzu Corporation, Tokyo, Japan

@@ Shofu Corporation, Kyoto, Japan 
light-cured for $60 \mathrm{~s}$, then the teeth were stored in water at $37^{\circ} \mathrm{C}$ for 24 hours. Following this, the teeth were sectioned bucco-lingually from the labial surface using a diamond saw under water spray, and polished with wet 600 grit silicon carbide paper. To detect the presence of gap formation between the resin and cavity floor, two methods were employed. The first technique was to place the cut specimens in Acid Fuchsin for $30 \mathrm{~s}$, rinse in water, and then observe under a dissecting microscope at 40 times magnification. Each specimen was scored from 0 to 3 , depending on the presence and size of the gap determined by a set of standard diagrams as previously described by Hosoda et al. ${ }^{11)}$ (Fig. 2). One individual, with previous experience in this test, scored every sample inspected. The second method of observation of the contraction gap was by making replicas of the polished surface. After polishing, each specimen was etched with $0.5 \mathrm{~N}$ hydrochloric acid for $30 \mathrm{~s}$ before taking a silicone impression in which was poured an epoxy resin to make the replicas. The replicas were then gold sputter-coated and observed by SEM.

The total test scores for each experimental group were combined to calculate a single figure.

To determine if a correlation existed between the tensile bond test and the gap test data, a first order regression analysis was carried out at the $95 \%$ level of confidence.

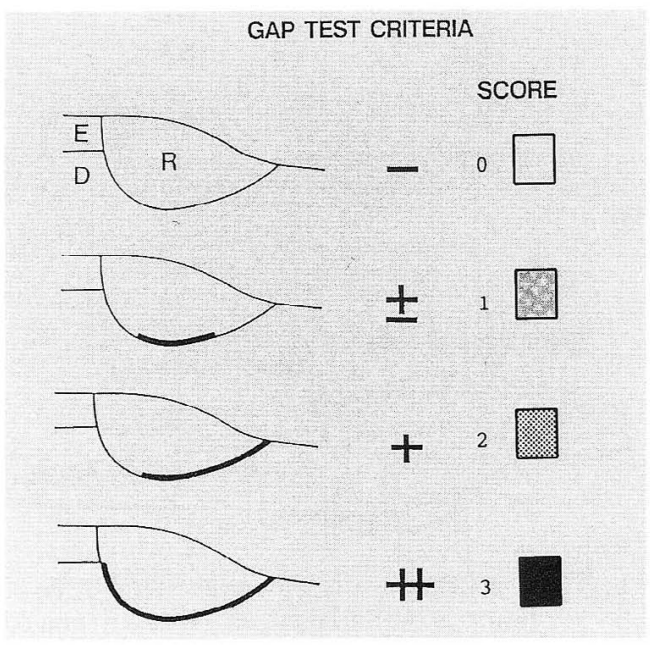

Fig. 2 The set of standard diagrams used for the gap test. $\mathrm{E}=$ enamel, $\mathrm{D}=$ dentin, and $\mathrm{R}=$ resin.

The scores rate from $0(-)$ no gap ; $1( \pm)$ gap is located at the center of the cavity ; $2(+)$ gap extending from the root surface margin to the base of the cavity floor; 3 $(++)$ gap extending along the complete cavity floor. 


\section{RESULTS}

The results for the tensile bond test are illustrated in Table 3, which indicates four statistically significant groups. The minimum bond strength recorded was $64.3 \mathrm{kgf} / \mathrm{cm}^{2}$ for group 1 and ranged up to a maximum strength of $151.8 \mathrm{kgf} / \mathrm{cm}^{2}$ in group 5.

The results for the gap test and the aggregate scores are displayed in Fig. 3. All groups exhibited the presence of gap formation, the worst being group 2, the best being group 5 (Fig. 3). The regression analysis test of the tensile bond data and gap test results produced a not significant, inverse correlation, $(\mathrm{R}=-0.65)$.

Table 3 Tensile bond test results

\begin{tabular}{cc}
\hline Group No. & $\mathrm{kgf} / \mathrm{cm}^{2}( \pm \mathrm{SD})$ \\
\hline 1 & $64.3(37.3)$ \\
2 & $66.0(29.5)$ \\
9 & $66.3(9.3)$ \\
3 & $76.4(31.6)$ \\
7 & $102.9(50.2)$ \\
8 & $104.2(14.4)$ \\
4 & $114.2(53.1)$ \\
6 & $133.7(33.1)$ \\
5 & $151.8(38.8)$
\end{tabular}

Groups on the same vertical line are not significantly different $(p>0.05)$

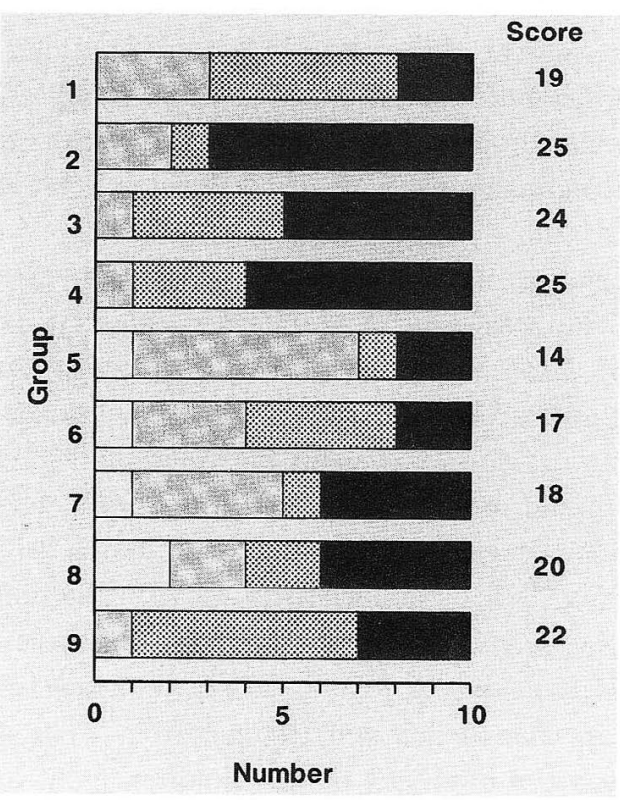

Fig. 3 Distribution of degree of yap formation for each group. The numerical figure is the total aggregate score for each group. 


\section{DISCUSSION}

The data for the tensile bond test showed a typically wide variation in the standard deviations for each group. The results indicated that the use of phosphoric acid conditioning with PA, followed by immediate curing (group 3) produced a similar bond strength as the no etch, immediate cure group (group 1). This same result was also observed when compared with the control material, PB. No difference could be detected between the no-etch PA groups (groups 1 and 2) or the control (group 9). It appears that even when no surface conditioning is performed, PA can penetrate or disrupt the smear layer, and perhaps infiltrate the dentin surface. This might be explained by the acidic nature of this bonding material, which is believed to have a pH of about 1.3. Also, the chemical composition may be such that PA is able to wet the dentin surface very easily. A previous report by Watanabe et al. ${ }^{12)}$ indicated that the phosphate ester monomer of Phenyl-P in a light-cured bonding system promoted the infiltration of monomers into the dentin through the smear layer, obtaining a bond strength of $6 \mathrm{MPa}\left(61 \mathrm{kgf} / \mathrm{cm}^{2}\right)$. It is believed that PA may produce a similar effect as the experimental bonding resin of Watanabe et $a l^{12}$. However, when the dentin was etched and the bonding resin left for $20 \mathrm{~s}$ prior to curing, the bond strength showed a significant increase (group 4). The reason for this is believed to be related to an increased infusion of the resin into the dentinal tubules and decalcified intertubular dentin. This factor would obviously enhance the stability and strength of the bond. The possibility that further etching may also have occurred due to its low $\mathrm{pH}$. However, the improvement of bond strength by waiting prior to curing was not the case when CA conditioning was performed. This might be due to the lesser degree of etching produced by $\mathrm{CA}^{8}$, thus implying that the monomers can immediately penetrate the decalcified dentin and dentinal tubules ${ }^{13}$. It should, however, be noted that the standard deviation for the immediate cure group (group 7) is about 3.4 times larger than the $20 \mathrm{~s}$ wait group (group 8), indicating that the bond stability is much improved in this latter group.

Where etching and priming agents were used together, large increases in the bond strength were recorded. The best result was obtained using GL (HEMA in glutaraldehyde) (group 5), which has shown good bond strengths in a previous study ${ }^{2}$. Several specimens from this group showed small areas of cohesive failure within the dentin, which was not noticed in any other group. The comparison between the SA-primed, phosphoric acidconditioned group (group 6) and group 5 was not significant. The increased bond strength observed in the GL-and SA-primed groups may be related to an alteration of the exposed collagen fibers by the primers after demineralization from etching, and also the enhanced infusion of the resin into the decalcified, primed collagenous layer ${ }^{14}$.

All gap test specimens showed gap formation between the resin composite and dentin, producing a similar result as that of Soh and Henderson ${ }^{15}$. The actual location of the gap, whether it occurred between the interface of the bonding agent and the dentin, or bonding agent and resin could not be determined, although numerous repilicas showed resin tags which had pulled out of the dentinal tubules when viewed by the SEM (Fig. 4). The most frequent location of gaps were at the deepest portions of the cavity floor which is what would 
be expected ${ }^{16)}$ (Fig. 5). This area is the region where greatest contraction of the resin composite will occur during curing, as well as being the region of poorest adhesive strength due to the fact that the tubules tend to be wider and open, which allows a greater presence of dentinal fluid that can interfere with bonding.

This point seems to be confirmed when the bond and gap test results are compared in the instances where the resin was left for 20 or $60 \mathrm{~s}$ prior to curing. For the bond test, the adhesive surfaces were located in superficial dentin. These results showed an increase in bond strength when the resin was left prior to curing, whereas the gap test specimens, with the bonding surface being located in deeper dentin, showed marked worsening in the size of the gap formed. Previous studies ${ }^{17-20)}$ have shown significant differences between the bond strengths to dentin when either superficial or deep dentin surfaces are used. In several instances, the gap increased to include the cavity cavosurface margin at the cementum. A further point of interest was that gaps were never observed at the enamel margin. Hence the possibility that the strength of the bond to enamel probably increased the likelihood of the formation of gaps at the cementum margin.

The use of priming agents appears to improve the bond strength to dentin, but gaps still form at the resin-dentin interface, although the widths of the gaps observed were generally smaller. Using GL produced the best results in the gap test.

Thus from the clinical standpoint, it appears that it is necessary to cure the bonding resin as quickly as possible to prevent contamination of the cavity surface by dentinal fluid, since it will reduce the degree of penetration of the resin into the conditioned dentin, thus allowing gap formation. Alternatively, and possibly more practical, especially in the case of a very deep cavity where dentinal fluid flow is likely to be higher, the placement of a glass ionomer lining cement in the deepest portions of the cavity, and then subsequent conditioning and priming of the dentin is recommended. Using this technique will both help reduce fluid contamination as well as decrease the overall cavity depth, and hence overall volume of resinous material, which can influence gap formation during curing. This situation would also allow the bonding resin to be left in situ for at least $20 \mathrm{~s}$ prior to curing, which as

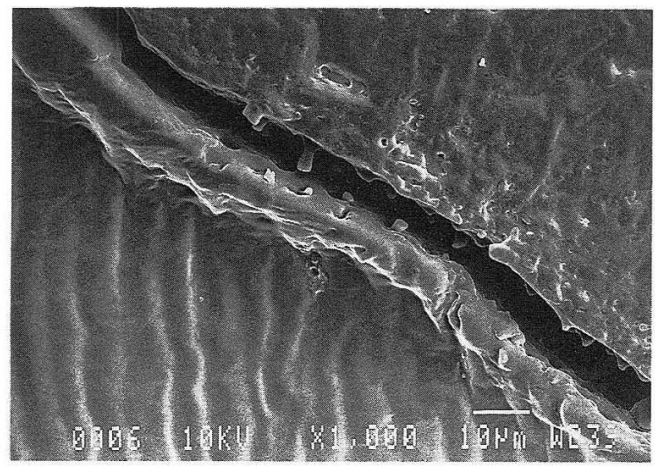

Fig. 4 SEM photograph of a replica showing the typical pattern of resin tags pulling out of the dentinal surface at the interface of the gap.

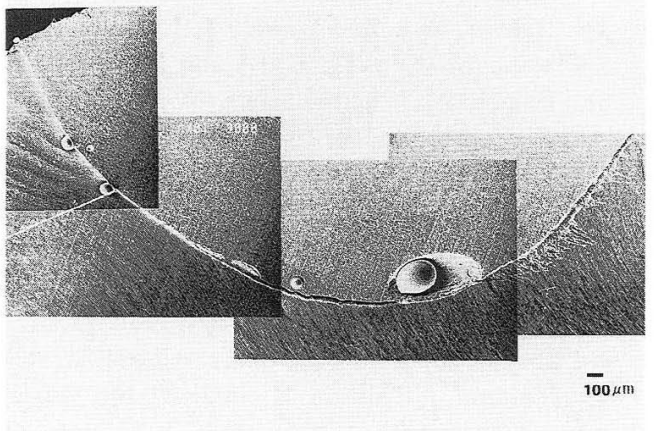

Fig. 5 SEM montage photograph showing the whole cavity outline with the typical type of gap formed, the largest area of gap is located at the base of the cavity. 
indicated from the results of this study, will improve both the bond strength and stability of the resin to the non-lined portion of the conditioned dentinal surface.

The idea behind such a material as PA, which does not condition the dentin is threefold. Firstly, the philosophy that retaining the smear layer may in some way protect the pulp from toxic by-products; secondly, strong etching materials, such as phosphoric acid, cause a considerable degree of damage to the dentin which should be avoided; and thirdly, that by not conditioning or priming, the chances for operator technique error are reduced. However, the results of this study indicate that although a similar bond strength to the control material (PB) can be obtained without etching, much higher bond strengths and reduced gap formation can only be achieved when both etching and priming are used.

\section{CONCLUSION}

The bond strength to dentin of PA without conditioning is the same as the control resin (PB) which used acid conditioning for the dentinal surface preparation.

An increased bond strength was obtained when the bonding resin was left for at least 20 seconds prior to curing. However, the highest bond strengths were obtained when a combinations of conditioning and priming were carried out. It is suggested that this system could be significantly improved if conditioning and priming are carried out prior to the bonding resin placement.

Although high bond strengths could be obtained, this does not necessarily mean that the resin composite will remain closely adapted to the cavity floor after curing.

\section{REFERENCES}

1) Reinhardt, J. W. and Capilouto, M. L. : Composite resin esthetic dentistry survey in New England, $J$ Am Dent Assoc 120 : 541-544, 1990.

2) Asmussen, E. and Munksgaard, E. C. : Bonding of restorative resins to dentin promoted by aqueous mixtures of aldehydes and active monomers, Int Dent J 35: 160-165, 1985.

3) Bowen, R. L., Tung, M. S. and Blosser, R. L. : Dentin and enamel bonding agents, Int Dent J 37 : 158 $-161,1987$.

4) Blosser, R. L. and Bowen, R. L. : Effects of purified ferric oxalate/nitric acid solutions as a pretreatment for the NTG-GMA and PMDM bonding system, Dent Mat $4: 225-231,1988$.

5) Finger, W. I. and Ohsawa, M. : Effect of bonding agents on gap formation in dentin cavities, Oper Dent 12 : 100-104, 1987.

6) Jorgensen, K. D., Itoh K., Munksgaard, E. C. and Asmussen, E. : Composite wall-to-wall polymerization in dentin cavities treated with various bonding agents, Scand J Dent Res 93: 276-279, 1985.

7) Brannstrom, M. : Infection beneath composite resin restorations : can it be avoided ? Oper Dent 12 : 158-163, 1987.

8) Hosoda, H., Hirasawa, K. and Fujitani, M. : New tooth surface conditioning for adhesion to composite restorations, Japan J Conserv Dent $32: 421-433$, 1989. (in Japanese)

9) Tagami, J., Hosoda, H., Imai, Y. and Masuhara, E. : Evaluation of a new adhesive liner as an adhesion promoter and a desensitizer on hypersensitive dentin, Dent Mater J 6 : 201-208, 1987.

10) Hosoda, H., Fujitani, M., Negishi, T. and Hirasawa, K. : Evaluation of newly designed adhesive liners containing salicylic acid derivatives as adhesion promoter, Japan J Conserv Dent 31 : 72-78, 1988. (in Japanese)

11) Hosoda, H., Fujitani, M., Negishi, T. and Hirasawa, K.: Effect of a series of new cavity surface 
treatments on bond strength and wall adaptation of adhesive composite resins, Japan J Conserv Dent 32: 656-665, 1989. (in Japanese)

12) Watanabe, I., Nikaido, T. and Nakabayashi, N. : Adhesion to ground dentin-investigation of bonding agent, Japan J Conserv Dent 33: 138-143, 1990. (in Japanese)

13) Inokoshi, S., Hosoda, H., Harnirattisai, C., Shimada, Y. and Tatsumi, T.: A study on the resin impregnated layer of dentin part 1. A comparative study on the decalcified and undecalcified sections and the application of argon ion beam etching to disclose the resin impregnated layer, Japan J Conserv Dent 33 : 427-442, 1990. (in Japanese)

14) Sugizaki, J.: The effect of the various primers on the dentin adhesion of resin composites-SEM and TEM observations of the resin impregnated layer and adhesion promoting effect of the primers, Japan $J$ Conserv Dent 34: 228-265, 1991. (in Japanese)

15) Soh, G. and Henderson, L. J. : Contraction patterns in cavities tested with two dentin bonding agents, Oper Dent 15: 167-172, 1990.

16) Davidson, C. L., deGee, A. J. and Feilzer, A.: The competition between the composite-dentin bond strength and the polymerization contraction stress, $J$ Dent Res 63: 1396-1399, 1984.

17) Mitchem, J. C. and Gronas, D. G. : Effects of time after extraction and depth of dentin on resin dentin adhesives, J Am Dent Assoc 113: 285-287, 1986.

18) Suzuki, T. and Finger, W. J. : Dentin adhesives: site $v$ s. bonding of composite resin, Dent Mater 4 : 379-383, 1988.

19) Tagami, J., Tao, L. and Pashley, D. J.: Correlation among dentin depth, permeability, and bond strength of adhesive resins, Dent Mater 6: 45-50, 1990.

20) Tagami, J., Komurai, H., Hirasawa, K., Burrow, M. F. and Hosoda, H. : A study on bond strengths of resin materials to deep dentin, Adhesive Dentistry 8:163-168, 1990. (in Japanese) 


\title{
本号掲載論文の和文抄録
}

\author{
新しいデンチンボンディング材の引張接着強さとギャップ形成について \\ M. F. BURROW, 林田桃子, 根岸 正, 二階堂徹 \\ 田上順次, 高津寿夫, 細田裕康 \\ 東京医科歯科大学歯学部歯科保存学第一講座
}

新しいデンチンボンディング材を用いて, 象牙質の前 処理, プライミング処理の影響について, 引張試験, ギ ヤップテストを行って検討した. 引張試験の結果, 前処 理およびプライマー処理の有無によって接着強さに有意 な差が認められ,リン酸による前処理と HEMA, グルタ ルアルデヒドを含むプライマーの組み合わせで 151.3 $\mathrm{kgf} / \mathrm{cm}^{2}$ と最も高い接着強さが得られた。一方, ギャップ テストの結果, すべての群においてギャップの形成が認
められたが, その様相は様々であり, ばらつきが大きか つた. また, 引張接着強さとギャップ形成との間には, 統計学的な相関は認められなかった，以上より，新しい ボンディング材はどの群においてもほぽ良好な接着強さ を示すと思われるが, 酸処理およびプライマー処理の併 用によって最も高い接着強さが得られ，ギャップを最小 にできることがわかった.

実験室的にリン酸八カルシウムのアパタイトへの転化に影響を与える因子

伴 清治, 松浦 満, 有本憲弘, 林崎順子, 伊藤泰明

長谷川二郎

愛知学院大学歯学部歯科理工学講座

調製したままの乾燥前のリン酸八カルシウム $(\mathrm{OCP})$ 沈殿物と乾燥条件の異なる 3 種の $\mathrm{OCP}$ 粉末を 3 週間, 11 種の生理的溶液に浸漬した. この溶液は $\mathrm{Ca}^{2+}, \mathrm{Mg}^{2+}$, $\mathrm{K}^{+}, \mathrm{Na}^{+}, \mathrm{HCO}_{3}{ }^{-}, \mathrm{HPO}_{4}{ }^{2-}, \mathrm{F}^{-}$, アルブミン, コラー ゲン,アルカリフォスファターゼより構成されている. また, ある溶液で $\mathrm{pH}$ を 3 つに変えた場合, 温度を 3 段階 に変えた場合についても浸漬実験をした，X線回折の測 定結果より, OCP は $\mathrm{Mg}^{2+}$ を含まない溶液への浸漬後は 結晶性の低いアパタイトにほとんど転化していた。その $\mathrm{X}$ 線回折の強度変化より求めた $\mathrm{OCP}$ の転化量について
行った分散分析結果より, OCP のアパタイトへの転化は 溶液の種類， $\mathrm{pH}$, 温度に対して有意差があり (危険率 1 \%以下),一方乾燥条件についての有意差は認められなか つた(危険率 $5 \%$ 以上). また, 赤外分光分析スペクトル より, $\mathrm{Mg}^{2+}$ を含まない溶液中で $\mathrm{OCP}$ から転化するアパ タイトは $\mathrm{CO}_{3}$ が含まれているが, $\mathrm{Mg}^{2+}$ を含む溶液中では ほとんど変化がなかった.これらの結果は溶液中での $\mathrm{Mg}^{2+}$ の存在が OCP からアパタイトへの転化に対し, 最 も効果的な因子であると考えられた。 